Canadian Science Publishing

Environmental Reviews Dossiers environnement

\title{
Sublethal consequences of urban life for wild vertebrates
}

\begin{tabular}{|r|l|}
\hline Journal: & Environmental Reviews \\
\hline Manuscript ID & er-2016-0029.R1 \\
\hline Manuscript Type: & Review \\
\hline Date Submitted by the Author: & 11 -Jun-2016 \\
\hline Complete List of Authors: & $\begin{array}{l}\text { Birnie-Gauvin, Kim; Carleton University, Department of Biology and } \\
\text { Institute of Environmental Science } \\
\text { Peiman, Kathryn; Carleton University, Department of Biology and Institute } \\
\text { of Environmental Science } \\
\text { Gallagher, Austin; Carleton University, Department of Biology and Institute } \\
\text { of Environmental Science; Beneath the Waves; University of Miami } \\
\text { Rosenstiel School of Marine and Atmospheric Science } \\
\text { de Bruijn, Robert; Max Planck Institue for Ornithology; Carleton University, } \\
\text { Department of Biology and Institute of Environmental Science } \\
\text { Cooke, Steven; Carleton University, Department of Biology and Institute of } \\
\text { Environmental Science }\end{array}$ \\
\hline Keyword: & $\begin{array}{l}\text { urban ecology, urbanization, vertebrates, sublethal consequences, } \\
\text { synurbanization }\end{array}$ \\
\hline
\end{tabular}

\section{SCHOLARONE'}

Manuscripts 
5 Kim Birnie-Gauvin ${ }^{1 *}$, Kathryn S. Peiman ${ }^{1}$, Austin J. Gallagher ${ }^{1,3,4}$, Robert de Bruijn ${ }^{1,2}$ and

6 Steven J. Cooke ${ }^{1}$

$8 \quad{ }^{1}$ Fish Ecology and Conservation Physiology Laboratory, Department of Biology and Institute of 9 Environmental Science, Carleton University, 1125 Colonel By Drive, Ottawa, ON, Canada K1S $10 \quad 5 \mathrm{~B} 6$

$11{ }^{2}$ Max Plank Institute for Ornithology, Eberhard-Gwinner-Str., 82319 Seewiesen, Germany

$12{ }^{3}$ Beneath The Waves, Incorporated., Syracuse, NY, USA

$13{ }^{4}$ Rosenstiel School of Marine and Atmospheric Science, University of Miami, Miami, FL 1433149 , USA

15

$16 *$ Author for Correspondence: kimbirniegauvin@cmail.carleton.ca 


\section{Abstract}

25 Urbanization is modifying previously pristine natural habitats and creating "new" ecosystems for

26 wildlife. As a result, some animals now use habitat fragments or have colonized urban areas.

27 Such animals are exposed to novel stimuli that they have not been exposed to in their

28 evolutionary history. Some species have adapted to the challenges they face - a phenomenon

29 known as synurbanization - while others have not. Here we present a review of the sublethal

30 consequences of life in the city for wild vertebrates, and demonstrate that urban animals face an

31 almost completely different set of physiological and behavioural challenges compared to their

32 rural counterparts. We focus on the negative fitness-related impacts of urbanization, but also

33 identify instances where there are benefits to wildlife. The effects of urbanization appear to be

34 both species- and context-dependent, suggesting that although the field of urban ecology is far

35 from nascent, we are still just beginning to understand how the intricacies of biodiversity on our

36 planet are affected by our presence.

37

38 Keywords: urban ecology, urbanization, vertebrates, sublethal consequences, synurbanization 


\section{Introduction}

The growth of cities is seen as the cornerstone achievement of human civilization (Childe

41 1950). In order to make a suitable living place, humans have modified natural landscapes by

42 clearing land, moving watercourses, and building infrastructure; in essence, dominating the

43 landscape (Vitousek et al. 1997). Today, more than half of the world's population lives in cities.

44 By 2030 , more than $60 \%$ of the population will live in urban areas (United Nations Population

45 Fund 2007), necessitating continuing landscape modification, especially in developing countries

46 (Cohen 2006). Humans have now spread into new landscapes and colonized natural areas or

47 rural lands that were previously pristine (Marzluff et al. 2001). The contemporary city is home to

48 many animal populations (Savard et al. 2000; Ditchkoff et al. 2006) that are exposed to novel

49 stimuli and challenges that did not exist in their evolutionary past (Kowarik 2011). The extent to

50 which animals can cope with these urban environments will affect all aspects of their fitness and

51 survival.

52 Scholars have studied the ecology of urban environments for decades (McDonnell 2011)

53 and this discipline, now known as "urban ecology" (Alberti 2008; Breuste et al. 2013), has

54 spawned books, publications, dedicated journals (e.g., Urban Ecosystems, Journal of Urban

55 Ecology), professional societies, and conferences. The discipline has advanced from simply

56 documenting urban species to developing theoretical approaches (Niemela 1999) and unifying

57 frameworks (Pickett et al. 2008). There have been nearly 500 studies investigating this topic in

58 animals since 1971 with more than $50 \%$ of them occurring between 2000 and 2010 (Magle et al.

59 2012). We have detected species and behaviors in places we thought they would never exist, and

60 we now understand that while some species suffer from urban living, others actually benefit and

61 thrive (McKinney 2006; Bonier et al. 2007b; Lowry et al. 2013). This case is best exemplified by 
62 the grey squirrel (Sciurus carolinensis), which was almost eradicated following the industrial

63 revolution in New York, only to be later reintroduced to entertain people and remind them of

64 "nature" (Stein 2014). Today squirrels are so successful they are entrenched in our lives and

65 people do not notice them. However, there is an increasing realization that wildlife residing in

66 urban environments differ from rural counterparts as a result of adaptation to anthropogenic

67 stressors - a process termed "synurbanization" (Luniak 2004).

68 While there have been a number of reviews on aspects of urban living in animals, they

69 tend to focus on either a specific taxonomic group (e.g., birds [Chace and Walsh 2006]) or

70 environmental issue or threat (e.g., road collisions [Coffin 2007], stormwater management

71 [Walsh et al. 2005]), often with an emphasis on lethal aspects (e.g., bird strikes [Klem 1989]) or

72 the presence or absence of species. To our knowledge, there have yet to be any reviews or

73 syntheses that focus on the sublethal consequences (in terms of metabolism, reproduction,

74 nutrition, etc.) of life in the city on vertebrates. This is surprising, since sublethal impacts on

75 animals can have far-ranging effects on the viability of populations and ecosystems (Calow and

76 Forbes 1998). Research focused on sublethal aspects of life in the city has only become popular

77 in the last few decades and is regarded as a priority research area (Magle et al. 2012). A review

78 of the sublethal effects of urban life on wild vertebrates would enable us to gain a deeper

79 understanding of the effects of urbanization on biological systems across a range of taxa, which

80 in turn may allow us to better understand how species will respond in the future to ongoing

81 development and urbanization. Ideally, such information could enable urban planners to buffer

82 these negative effects on wildlife. In this paper we first provide an overview of the general

83 challenges that define life in the city for vertebrates. Next we consider how urban living

84 negatively impacts seven biologically-relevant components of organismal function central to 
85 animal ecology and fitness: metabolism and respiration, glucocorticoids, nutrition, locomotion

86 and activity, communication, reproduction, and disease and immune function. For all sections we

87 attempt to integrate elements of behavior and physiology given the inherent difficulty of

88 decoupling these concepts when dealing with wild animals (Cooke et al. 2014). We also address

89 some of the key benefits for species that thrive in cities (i.e., synurbanization; see Figure 1).

90 Lastly, we consider how the knowledge of these sublethal effects can help urban planners make

91 cities more livable for wildlife. Our synthesis focuses on vertebrates that reside in urban areas

92 including birds, mammals, fish and herpetofauna.

\section{2. Challenges that define city life}

94 In cities, humans purchase food at stores, select clothing geared to weather conditions,

95 seek shelter to sleep, and use a variety of transportation methods, most notably vehicles on roads,

96 to move ourselves and the goods that we need. Wild vertebrates need to functionally do the

97 same things - obtain resources (goods), live safely and within their environmental tolerances

98 (shelter), and move among areas to maximize fitness (transportation). However, an urban

99 environment looks much different to a wild animal than it does to a human (Alberti and Marzluff

100 2004). We recognize that the generalities discussed here vary with climate (some areas do not

101 receive snow, some are arid, etc.), development standards (e.g., type of infrastructure), and

102 wealth, though in other cases patterns are evident both on a global scale (e.g., between cities in

103 developing vs developed countries) and also within cities (e.g., between shanty-towns and

104 suburban areas with large single-family dwellings; Alberti 1999). There can be dramatic

105 variation in the physical footprint of an urban area as well as the density of human dwellers.

106 What is clear is that the complexity of urban environments and anthropogenic activities make it

107 difficult to evaluate and understand the specific mechanisms by which urbanization changes the 
108 structure of communities and function of ecosystems (Booth et al. 2004; Alberti 2005), given

109 that these challenges posed to urban wildlife do not occur in isolation from each other. A brief

110 overview of the complex changes urbanization creates throughout the landscape is illustrated in

111 Figure 2.

112 The first step in urbanization is often land clearing followed by the installation of services

113 such as sewer, water and electricity and associated roads. The clearing of land tends to remove

114 shade and riparian vegetation from streambanks which decreases habitat complexity and

115 increases erosion and water temperature (Walsh et al. 2005). Residential dwellings and other

116 buildings (e.g., for manufacturing and service) follow. Pavement, concrete, shingles and other

117 building materials are generally impervious to water such that precipitation rapidly moves from

118 the built landscape into stormwater management systems. Many urban streams have been

119 channelized and encased to be entirely subsurface (i.e., in pipes) which changes runoff patterns, a

120 process termed the "urban stream syndrome" (Walsh et al. 2005). The hydrograph following

121 precipitation events is often altered such that water levels rise and fall quickly with little

122 opportunity for infiltration (Paul and Meyer 2001; Meyer et al. 2005). Runoff from roads carries

123 a variety of substances including salt (used in winter to improve road safety), nutrients, fecal

124 material (from wildlife and humans), and hydrocarbons and heavy metals (from combustion

125 engines) into the stormwater system and downstream watercourses (Ball et al. 1998). Because of

126 the historical importance of water for transportation and our continued dependence on it as a

127 resource, most urban centers occur adjacent to estuaries, lakes, rivers or oceans such that

128 shoreline development and water pollution are common (Grimm et al. 2008). Urban centres are sources of heat and light pollution (Oke 1995; Longcore and Rich

130 2004). Furthermore, natural habitats tend to be scarce in the city, with the presence of large 
131 structures acting as barriers to the movement of animals (Cheisura 2004). The collective body of

132 infrastructure in urban areas both stores and generates heat - a phenomenon known as the urban

133 heat island effect where temperatures are generally several degrees warmer than in outlying areas

134 (Oke 1995). The urban heat effect is positively correlated with city size and population density

135 (Oke 1973; Brazel et al. 2000). At night or in low light conditions, artificial lighting is used to

136 aid human vision which casts very directed light in some areas (e.g., head lights, street lights)

137 and creates a more general "light haze" that surrounds urban areas - a phenomenon known as

138 “ecological light pollution” (Longcore and Rich 2004). Although modern cities contain parks

139 and many dwellings have yards, these are typically grass monocultures (Robbins and Sharp

140 2006) that lack the diversity of the native grasslands they have replaced. Extensive pesticide use

141 is often needed to maintain lawns and other ornamental vegetation within urban areas (Robbins

142 et al. 2001). True naturalized habitats are rare (Cheisura 2004) and where they do exist they tend

143 to be encroached upon by non-native vegetation (e.g., ornamentals planted by humans, invasive

144 species; Alvey 2006). The physical infrastructure also creates physical hazards or barriers to

145 movement for fish (dams [Larinier 2001], road crossings with perched culverts [Warren and

146 Pardew 1998]), birds (buildings; Klem 1989), and terrestrial vertebrates (buildings, roads; Coffin

147 2007). Human activities and infrastructure (especially from transportation) can also generate

148 extensive noise (e.g., sirens, engines; Cunniff 1977; Zannin et al. 2006).

149 Pollution is a growing problem in urban areas. Emissions from combustion engines,

150 industrial processes and burning of materials (e.g., garbage, wood, propane, natural gas or coal

151 for cooking) generates air pollution and contributes to smog (Mage et al. 1996). The mere

152 omnipresence of humans in urban areas also provides the opportunity for animals to be disturbed

153 - a phenomenon that is comparatively less common in rural or natural areas. Waste generated by 
154 humans can take several forms; where sewers exist, human excrement and other inputs (e.g.,

155 pharmaceuticals, food waste, chemicals) are directed to sewage treatment plants but they are

156 imperfect in their ability to remove all unwanted substances (Sharma and Sangi 2012). Solid

157 waste from household and industrial sources is often collected at regular intervals and taken to

158 central processing facilities although in some areas it is burned at source (Sakai et al. 1996). In

159 order to maintain our function in cities, all of these processes work simultaneously, throughout

160 the day, 365 days a year.

\section{3. Sublethal consequences of city life on biological systems}

162 Collectively, the various elements of urban environments have the potential to influence

163 the biology, ecology and health of wildlife. Here we briefly summarize with representative

164 examples the ways in which aspects of urban life influence the different components of organism

165 function (e.g., metabolism, locomotion, etc.) related to fitness.

\subsection{Respiration and metabolism}

In wild organisms, energy resources are often limited, and must therefore be allocated

168 efficiently to maximize fitness. Increases in respiration and metabolism lead to accelerated use of

169 energy stores, and could potentially lower fitness. Since the physiology of free-ranging animals

170 is directly influenced by their environment, the urban environment can drive changes in

171 metabolic rate and respiration, which could in turn affect life-histories (Ricklefs and Wikelski

172 2002). There is some evidence that community respiration (total ecosystem oxygen consumption

173 and primary production) increases as a result of increased urbanization in catchments. More

174 specifically, it is predicted that respiration will increase for both thermoregulator and

175 thermoconformer fish species, as well as for the platypus, Ornithorhynchus anatinus (Serena and 
176 Pettigrove 2005; Walsh et al. 2005), a trend thought to be predominantly driven by urban

177 stormwater runoff (Walsh et al. 2005).

178 The increased temperature from the urban heat island effect can add substantial strain on

179 the thermoregulatory mechanisms (Kleerekoper et al. 2012) and metabolism of individuals.

180 Metabolic rates, notably oxygen consumption and nitrogen excretion, increase as a result of

181 elevated temperature in a variety of taxa (Morgan et al. 2001), suggesting that individuals in an

182 urban environment would have increased metabolic rates, most prominently affecting

183 ectothermic species. In addition, elevated temperatures can lead to an increased rate of protein

184 degradation in the lab (e.g., Houlihan et al. 1995). Though few studies have investigated the

185 direct impacts of heat islands on wild vertebrates, some studies have linked global climate

186 change to impairments in energy metabolism (e.g., Sokolova and Lannig 2008), suggesting that

187 the heat island effect will have negative consequences on the metabolism of urban wildlife.

188 Pollution is a growing concern in cities around the world. While many pollutants have

189 made their way into the atmosphere and water, ammonia is the most manufactured molecule in

190 the world and has rapidly polluted the environment (Atkins 1987). Organisms subjected to

191 ammonia suffer metabolic costs (Calow 1991), including greater rates of protein synthesis (Reid

192 et al. 1998), a finding generally associated with increased oxygen consumption and overall

193 elevated metabolic rate. Maintaining an elevated metabolic rate quickly becomes costly and

194 leads to decreased growth (Steyermark 2002). In the long-term, pollution will likely have

195 significant negative effects on the metabolism and respiration of urban wildlife. Moreover,

196 evidence suggests that warming temperatures and metal pollution have interactive effects on the

197 metabolism of aquatic ectotherms, which in the long-term could have repercussions on growth, 
198 reproduction and locomotion of animals living in urban waters (reviewed in Sokolova and

199 Lannig 2008).

$200 \quad 3.2$ Glucocorticoids

201 Allostasis is the process of maintaining homeostasis in the face of changing

202 environmental and physiological conditions (McEwen and Wingfield 2003). Measures of

203 glucocorticoids such as cortisol and corticosterone (the primary stress hormones for

204 fish/mammals and rodents/birds/reptiles respectively) have been widely used to estimate

205 allostatic load, defined as the current and predicted energetic demands that an organism faces

206 (Dantzer et al. 2014). Several studies have used this approach to investigate the effects of

207 urbanization on animals. Baseline corticosterone of non-breeding male white-crowned sparrows

208 (Zonotrichia leucophrys) was higher among urban than rural individuals (Bonier et al. 2007a).

209 However, urban European blackbirds (Turdus merula) (Partecke et al. 2006) and dark-eyed

210 juncos (Junco hyemalis) (Atwell et al. 2012) had lower corticosterone levels after being exposed

211 to an artificial stressor than those in rural environments, providing evidence that species may

212 respond differently to urban stressors. For example, Nestling white-crowned sparrows

213 (Zonotrichia leucophrys oriantha) near roads with traffic had increased baseline and stress-

214 induced corticosterone levels compared to nestlings that lived further away from roads (Crino et

215 al. 2011). However, baseline and stress-induced corticosterone levels in nestling American

216 kestrels (Falco sparverius) did not vary with measures of human disturbance such as traffic

217 speed and volume (Strasser and Heath 2011), findings which support the hypothesis that species

218 differences in the response to urban stressors exist. Furthermore, Atwell et al. (2012) suggested

219 that boldness and stress responsiveness through the hypothalamic-pituitary-adrenal axis were 
220 highly influenced by the urban environment, which suggests that personality and behavior may

221 play an important role in the stress response.

222 While there is extensive literature on the endocrine ecology of urban avian species

223 (review by Bonier 2012), few studies have addressed how glucocorticoid homeostasis is

224 disturbed as a result of urbanization in non-avian animals. In squirrel gliders (Petaurus

225 norfolcensis), hair-based cortisol concentrations were higher in individuals living adjacent to

226 major roads than those residing within interior habitats (Brearley et al. 2012). In contrast,

227 urbanized tree lizards (Urosaurus ornatus) in the southwestern United States exhibited lower

228 baseline and stress-induced corticosterone concentrations than rural ones (French et al. 2008).

229 Belanger et al. (2016) found that variation in baseline and acute cortisol concentrations in central

230 mudminnows (Umbra limi) was independent of the level of urban stream degradation. This small

231 sample of studies show a large amount of variation in stress responses among taxa, suggesting

232 that impacts of urbanization on glucocorticoids (both baseline and stress-responsiveness) are

233 either species or context-dependent.

$234 \quad 3.3$ Nutrition

235 Nutritional ecology links field ecology with animal phenotypes, as the acquisition of 236 nutrients affects how organisms interact amongst themselves and with the environment

237 (Raubenheimer et al. 2009; Simpson et al. 2010), especially as individuals deal with a changing

238 world (Raubenheimer et al. 2012). Both the quality and quantity of food items have direct and

239 indirect effects on fitness. Pollutants can often make their way into food items and may alter

240 fitness. For example, tadpoles had reduced mass when exposed to organophosphate pesticides

241 commonly used in urban areas, and smaller tadpole mass can lead to reduced fecundity and

242 survival in adults (Widder and Bidwell 2008). Pollutants can also travel through the food chain. 
243 In urban sites, both common blackbirds (Turdus merula) and their earthworm prey had higher

244 lead concentrations than in rural areas (Scheifler et al. 2006). Six of seven species of passerine

245 birds exhibited higher lead in their blood in urban compared to rural environments; nestlings of

246 two of the species also had higher lead in urban than rural environments, and for one species this

247 was correlated with reduced body condition (Roux and Marra 2007). Interestingly, ground

248 feeders had higher levels of lead than canopy feeders, possibly due to leaded gasoline leaching

249 into the soil and concentrating in the ground-based food chain (Roux and Marra 2007).

250 Poisoning is an unintended consequence of urban prey selection, such as when anticoagulant

251 rodenticides are ingested by mountain lions (Puma concolor) and bobcats (Lynx rufus) making

252 them more susceptible to mange (Riley et al. 2007). In general, the presence of pollutants in food

253 items negatively impacts wild vertebrates, through both direct and indirect consumption.

254 Predictable anthropogenic food sources (dumps, middens, fishing discards, etc.) affect

255 many individual and population level parameters (reviewed in Oro et al. 2013). This food

256 provisioning can lead to problems such as increased aggression at feeding sites and malnutrition

257 (e.g., Newsome and Rodger 2008). Provisioned feeding can also have long-lasting consequences

258 by negatively affecting the following year's reproduction (Grieco et al. 2002; Plummer et al.

259 2013). Food pulses can also increase competition if more individuals of ecologically similar

260 species stay to breed (Jansson et al. 1981) and predation if more predatory individuals are

261 attracted to the food source (Marzluff and Neatherlin 2006; Morris 2005). The indirect effects of

262 supplementation are less studied. For instance, Saggese et al. (2011) found that supplemented

263 male great tits delayed their dawn chorus, which negatively affects mate acquisition. Other

264 indirect effects include shifts in peak insect abundance due to altered vegetative phenologies

265 driven by the urban heat island effect, which may result in a mismatch between chick rearing and 
266 food supply for birds (Penuelas and Filella 2001). Thus, both the quantity and quality of food is

267 affected by human activities, and their negative effects may vary by sex, age and personality

268 (reviewed in Oro et al. 2013).

269 Increases in nocturnal illumination from urban areas has also led to changes in foraging

270 behavior and predator-prey interactions. For instance, artificial light was shown to create

271 shadows in the night which hinder the visibility of surrounding predators, making prey more

272 vulnerable to predation (reviewed in Rich and Longcore 2013). These findings suggest that light

273 can affect the nutrition of wildlife through impacts on behavior.

\section{$274 \quad 3.4$ Locomotion and activity}

275 Spatially, urbanized habitats are complex mosaics with an altered availability and

276 structure of pathways and corridors that affects an organism's ability to access resources and

277 mates (Alberti 2005). Many studies have investigated how the locomotor activity and movement

278 patterns of vertebrates differ between urban and rural habitats. Both bat (Chiroptera) (Gehrt and

279 Chelsvig 2003) and coyote (Canis latrans) (McClennen et al. 2001; Grinder and Krausman

280 2001) activity levels were higher in urbanized landscapes than in rural areas. These findings

281 suggest that due to the presence of artificial lighting in urban areas, these animals can prey into

282 the night (McClennen et al. 2001). In the marine realm, bull sharks (Carcharhinus leucas)

283 throughout a developed coastal ecosystem off Australia avoided areas of high modification

284 (Werry et al. 2012), providing evidence that the effects of urbanization go beyond the boundaries

285 of the city. Animals can adapt their activity levels to urbanization in different ways. Fragmented

286 urban habitats can cause arboreal species to modify their movement. For example, Siberian

287 flying squirrels (Pteromys volans) avoided urbanized habitats by moving through them more

288 quickly (Mäkeläinen et al. 2016). Alternatively, some animals shift the timing of their activity. 
289 For example, coyotes and bobcats decrease their activity levels during daylight hours (Tigas et

290 al. 2002). In general, linear features associated with urbanization such as transportation corridors

291 inhibit the mobility of many species of birds (Crooks 2002, Tremblay and St. Clair 2009),

292 freshwater fish (Coutant and Whitney 2000), and large mammals (bobcats, Poessel et al. 2014).

293 Artificial light is altering natural light cycles extensively (reviewed in Gaston et al.

294 2014). Light now continues into the night, affecting the normal locomotion activities of many

295 animals such as foraging (Lebbin et al. 2007) and migration (reviewed in Navara and Nelson

296 2007). For example, many migratory animals (e.g., birds, turtles) can become attracted to or

297 disoriented by artificial illumination (reviewed in Longcore and Rich 2004), demonstrating that

298 important aspects of the life cycle of animals can be altered as a consequence of urbanization.

299 It appears that the locomotor activities of generalist species are not drastically affected by

300 urbanization, probably due to the fact that the availability of human-provisioned resources

301 offsets fitness-related costs associated with prey-searching (Oro et al. 2013). However,

302 fragmentation can be lethal or create significant costs to movement if urbanization occurs within

303 the entire home range of certain species (i.e., specialists). In these cases, there are likely to be

304 more dramatic changes such as restricted movement which could lead to decreased condition and

305 fitness. This is especially relevant for developing countries in the tropics that contain a greater

306 proportion of specialists, as maintaining natural areas around urbanized fragments will provide

307 greater conservation benefits.

$308 \quad 3.5$ Communication

309 Anthropogenic noise is ubiquitous in its effects across the globe and in the taxonomic

310 diversity of animals affected, and has been the subject of numerous reviews (Shannon et al

311 2015). It can be a source of stress for urban animals, as erratic sounds are perceived as threats 
312 and chronic sounds can lead to acoustic interference (i.e., acoustic masking, Francis and Barber

313 2013). To reduce the masking effects of anthropogenic noise, acoustically plastic individuals can

314 change the frequency, amplitude, or timing of their calls (Slabberkoorn 2013; Laiolo 2010;

315 Patricelli and Blickley 2006).Traffic noise is also associated with a reduction in the abundance

316 and diversity of avian migrants (McClure et al. 2013) and with decreased body condition of those

317 that stay (Ware et al. 2015), indicating that even among plastic species that remain in the 318 presence of noise there may be sublethal effects. Noise pollution can affect an individual's

319 ability to identify predators, defend against rivals, find mates, and identify offspring. For

320 instance, female house sparrows showed increased vigilance when exposed to chronic noise

321 (Meillere et al. 2015); anthropogenic noise led to ineffective parent-offspring communication

322 and lower body mass in house sparrow chicks (Schroeder et al. 2012); and noise impaired the

323 ability of larval fishes to locate suitable habitat (Simpson et al 2008). Noise pollution

324 additionally impairs the ability of animals to locate food, either directly in sonar-producing

325 animals or indirectly through reduced ability to communicate with group members. For example,

326 greater mouse-eared bats (Myotis myotis) reduced their foraging time and effort due to traffic

327 noise (Jones 2008).

328 There are numerous examples of species modifying their vocalizations in noisy

329 environments (Sol et al 2013 and refs therein). These modifications may be energetically costly

330 (Oberweger and Goller 2001) and can have unanticipated effects on communities (Naguib 2013),

331 such as when traffic noise indirectly increased the calling rate of the frog Rana nigrovittata due

332 to heterospecifics reducing their calling rate under noisy conditions (Sun and Narins 2005).

333 Whether other forms of communication, such as visual and chemical cues, are also affected by

334 anthropogenic changes have rarely been investigated (Candolin and Wong 2012). Nonetheless, it 
335 is clear that urbanization has extensive consequences on the communication of urban wildlife,

336 effects which can have negative repercussions on reproduction (mating calls), foraging (food

337 location) and population dynamics (acoustic interference).

\section{$338 \quad 3.6$ Reproduction}

339 Reproduction is often incompatible with a stressed state and successful reproductive

340 investment can only occur when there are sufficient resources available to devote to it.

341 Landscape alterations likely contribute to the higher breeding densities and longer breeding

342 seasons observed in a variety of urban wildlife (e.g., Walcott 1974; Cramp 1972). However,

343 urbanization does not have reproductive benefits for all wildlife. For example, female English

344 sole (Parophrys vetulus) from areas with high levels of water contaminants adjacent to urban

345 areas in Puget Sound, Washington, had more reproductive impairments and produced a lower

346 proportion of normal larvae compared to fish from non-polluted areas (Casillas et al. 1991).

347 Similarly, a study by Partecke et al. (2005) revealed that urban European blackbirds showed

348 earlier gonadal growth, secretion of luteinizing hormone (LH) and testicular development than

349 their rural counterparts. Pollutants are not the only source of alterations in reproductive activity

350 for urban wildlife. Artificial night light, which birds from urban centres are exposed to, appears

351 to cause early reproductive development (Dominoni et al. 2013). Furthermore, the same study

352 showed that city birds responded differently to light than their rural counterparts, exemplifying

353 once again that urbanization can change the physiological phenotype of organisms (Dominoni et

354 al. 2013).

355 Rubbo and Kiesecker (2005) investigated the effects of urbanization on the breeding

356 distribution of amphibians across wetlands along an urban gradient in Pennsylvania, USA. Urban

357 wetlands had lower larval amphibian species richness than rural areas. This was due to fewer 
358 wood frogs (Rana sylvatica) and salamanders (Ambystoma maculatum and A. jeffersonianum)

359 breeding and/or offspring survival in urban areas, suggesting that these species are highly

360 sensitive to urban development, while other species (Anura spp. [toads], Rana catesbeiana

361 [American bullfrog], Hyla versicolor [grey tree frog] and Notophthalmus viridescens [Eastern

362 newt]) appeared to be more resilient to the altered landscape. Big brown bats (Eptesicus fuscus)

363 and red bats (Lasirus borealis) from rural areas in Detroit, Michigan USA had fewer offspring

364 and lower population size in urban parks (Kurta and Teramino 1992). Taken together, these

365 findings suggest that life in the city affects the reproductive capabilities of some species but not

366 others, highlighting variation in the sensitivity of wildlife to urban development.

$367 \quad 3.7$ Disease and immune function

368 There is increasing interest in studying the relationship between urban life and the

369 emergence of wildlife diseases as urbanization may create shifts in host geographical ranges and

370 densities, interspecific interactions and contamination via pathogens (Daszak et al. 2000). In

371 coastal Florida, a pathogenic nematode in wading birds was only present in sites disturbed by

372 stream engineering and nutrient fluxes (Coyner et al. 2002). Similarly, in a study by Saldiva et al.

373 (1992), rats that were exposed to the urban air pollution of São Paulo, Brazil, for six months

374 developed inflammatory complications in their breathing airways, resulting in increased

375 respiratory failure, when compared to control rats kept in a clean city. These negative

376 repercussions on the health of wildlife as a result of urbanization have also been observed in

377 aquatic ecosystems. Helms et al. (2005) revealed that fish health (measured by the proportion of

378 fish with eroded fins, lesions and tumors) declined with increasing urbanization. In all of these

379 cases, pathogens and illnesses appear to be a direct result of developing urban areas. 
In the context of epidemiology, cities function as first points of entry for novel pathogens,

381 and provide opportunities for rapid amplification and cross-species contamination (ecology of

382 wildlife diseases review by Bradley and Altizer 2006). For example, grey squirrels were

383 introduced to the United Kingdom where they competed with native red squirrels (Sciurus

384 vulgaris). The gray squirrels also carried paramyxovirus and through these interspecific

385 interactions infected red squirrels, leading to a decline of the latter (Wauters and Grunell 1999;

386 Tompkins et al. 2002). In another example, the poultry bacterium Mycoplasma gallisepticum

387 infected wild songbirds in 1994, and may be spread when birds interact at feeders (Dhondt et al.

388 2014). Human interactions can also affect the immunity of wildlife. In the Southern sea otter

389 (Enhydra lutris nereis), infection with meningoencephalitic disease was greater in regions

390 associated with high human density (Miller et al. 2002). Thus, cities provide both the ideal

391 conditions for the spread of pathogens and diseases, and make animals more susceptible to those

392 diseases by lowering their immune function.

\section{$393 \quad 3.8$ Synthesis}

394 It is obvious that no two species are affected in the same manner by the process of 395 urbanization, and in fact, these effects likely differ even across sexes, life-stages, or ecomorphs.

396 Nevertheless, there do appear to be overall patterns in how key biological systems are affected,

397 although we did not rank the vulnerability of these systems. Some differences may also shift with

398 time-scale focus (i.e., physiology is acutely affected, fitness is chronically affected).

399 Furthermore, it is important to note that landscapes can vary, each bringing their own set of

400 challenges and affecting wildlife in different ways. For example, aquatic organisms are more

401 likely to be affected by stormwater runoff than birds, while skyscrapers are more likely to 
402 influence birds than solely ground-dwelling or aquatic organisms. This suggests that the 403 consequences of urban life on animals are both species- and context-dependent. While the urban life poses various challenges to core biological systems, the effects of 405 such challenges are not independent of each other, and their additive or synergistic effects are 406 rarely studied. For example, the city may cause an animal to spend more time foraging due to 407 habitat fragmentation, with success mediated by light pollution and the urban heat island effect, 408 which in turn lowers investment in offspring. There can also be inter-generational nature and 409 nurture effects which have yet to be explored in detail. Parents in poor condition may have 410 offspring with lower body condition, leading to increased susceptibility to pathogens and 411 decreased future reproductive success. Additionally, selection on foraging time may lead to food 412 specialization and a loss of ability to respond to future environmental changes if those changes 413 were to cause a decrease in food availability. Quite simply, life in the city for vertebrates means

414 exposure to a wide range of conditions and stressors that differ dramatically from what

415 organisms living in more pristine settings (e.g., rural environments, wilderness).

\section{4. Making cities more liveable}

417 Habitat loss, fragmentation, and degradation are the major threats to organisms living in 418 urban environments (McKinney 2002), and attenuating these threats are obvious first choices for 419 making cities more liveable for all vertebrates. Margules and Pressey (2000) suggested the 420 "node, buffer, corridor" principle for landscape-scale conservation. Nodes are high quality

421 habitats with little to no anthropogenic disturbances. Nodes are surrounded by buffer zones in

422 which human activity decreases with proximity to nodes. Corridors connect the nodes to create a

423 more accessible habitat network. This approach has been successful for many ungulates and 
424 large predators in suburban areas, especially in the context of highway crossings, but there are

425 few examples where this technique has been integrated directly into urban centres.

426 It is important to note that land use planning can be approached at local, regional, and

427 global scales. The addition of a green space (e.g., parks, nature reserves) within an urban

428 environment can have substantial benefits for many regional organisms such as squirrels and

429 birds (e.g., Flores et al. 1998; Chiesura 2004). The implementation of wild gardens in a yard

430 (Goddard et al. 2010) or living roof or living wall components (Francis and Lorimer 2011) can

431 enhance the fitness of local animals and increase biodiversity. However, the needs of animals can

432 vary extensively and must be accounted for when making land use planning or urban design

433 decisions. For example, some birds need mature forests to breed, while larger predators tend to

434 need large undisturbed habitats, and so planning should ideally also include natural areas of

435 various size and with various levels of disturbance.

436 Important actions to consider for restoration and the mitigation of urbanization effects on

437 wildlife include maintaining native vegetation and nesting structures, increasing foliage height

438 diversity, integrating urban parks in the native habitat system, reducing urban effects on remote

439 natural areas, and developing monitoring programs (Marzluff and Ewing 2001). Collaborative

440 planning and the spread of knowledge to appropriate stakeholders can provide significant

441 advantages for making cities more liveable. Addressing issues with water conveyance to promote

442 infiltration rather than stormwater runoff are sorely needed. In addition, there is a need to reduce

443 sources of pollution including light and noise. Furthermore, outreach programs about urban

444 wildlife and biodiversity may go a long way to educate city dwellers and instill a sense of

445 environmental stewardship in light of people's daily choices and the future threats facing urban 
446 animals (Andersson et al. 2014). We present successful approaches to making cities more livable

447 in Figure 3.

\section{$448 \quad$ 5. Conclusion and research needs}

449 As the knowledge base expands, it is apparent that, given the many challenges that urban

450 animal face, they can be severe consequences on their fitness. Certainly some aspects of urban

451 life are lethal (e.g., vehicle collisions and bird strikes) but the sublethal effects are even more

452 pervasive. The sublethal consequences are not independent of one another reflecting the

453 diversity of stressors and diversity of organismal responses. The core biological systems

454 described in this paper can be altered in complex, sometimes unexpected ways, making it

455 difficult to precisely predict how wildlife will respond to urban life and emerging stressors.

456 Based on our review, it became apparent that future research needs to consider the spatial,

457 temporal and biological (e.g., individual, population, community, ecosystem) scale of their study

458 to ensure that findings are relevant to planners and managers. In addition, many studies face

459 challenges with identifying appropriate "controls". The use of urban gradients (rather than true

460 controls) can be problematic because often the most sensitive species are already extirpated,

461 forcing studies to rely on the more available species, which are often generalists (e.g., Sorace and

462 Gustin 2009). There is little documentation on the evolutionary consequences of this ecological

463 sorting. Even for species that can tolerate life in the city, the majority of studies have taken an

464 ecological approach, with only a few investigating whether acclimatization to urbanization

465 occurs via phenotypic plasticity or whether it is a function of evolutionary dynamics (Lowry et

466 al. 2013). Urban environments tend to be more homogeneous in biotic and abiotic variables than

467 the natural environments they replace (plant composition, temperature, humidity etc.; Hall et al.

468 2016). This homogeneity may lead to a loss in genetic diversity and individual variation, which 
469 is the basis for natural selection. Synurbanization is an increasingly recognized phenomenon

470 (Figure 1) yet it is unclear what the long-term consequences of it are on organismal fitness and

471 the evolutionary trajectory of populations. In many cases, human population growth and

472 development is happening at such a rapid rate that the research community will lag in their

473 understanding of how species are affected by new stressors such as emergency exposures (oil

474 spills, nuclear power plant meltdowns, etc.), or other developing, synergistic changes.

475 Birds and small mammals continue to be the best-studied taxonomic groups with respect

476 to sublethal consequences on urban vertebrates. Other taxonomic groups continue to be less

477 studied, despite the recognition of this imbalance (Luniak and Pisarski 1994). Fish have received

478 relatively little attention (Magle et al. 2012); future work on aquatic organisms is sorely needed

479 as over half of the world's population lives near a coastline. Electronic tagging tools that enable

480 researchers to track the spatial movements and survival of wildlife combined with sensors (e.g.,

481 acceleration, heart rate, body temperature; see Wilson et al. 2015) and cameras/video will

482 provide researchers with important information on how urban wildlife interact with their

483 environment and other organisms (including humans; see O'Connell et al. 2010). Similarly, the

484 use of non-lethal sampling techniques and biomarkers (e.g., blood samples, fur and feathers for

485 glucocorticoids, scats for disease screening) provide us with new tools for connecting individual-

486 level condition and state with behaviour and other metrics of relevance to population-level

487 processes (Sheriff et al. 2011). Indeed, this integration of behavior and physiology (see Cooke et

488 al. 2014) is at the very core of urban ecology and will help us truly understand the long-term

489 fitness-related impacts on animals, making it an exciting, timely, and extremely collaborative

490 field of study. 

We have clearly shown that life in the city is not without sublethal consequences.

492 Despite the potential for synurbanization, the reality is that most urban wildlife experiences

493 negative effects compared to conspecifics in more rural/pristine locations, and that presumably

494 sensitive species have been replaced by generalists that are more robust to sublethal disturbances.

495 There are many ways in which urban life can alter the biology and ecology of vertebrates and we

496 encourage urban planners to create developments that support biodiversity and minimize

497 disturbance (Savard et al. 2000). Humans value urban wildlife (Alberti et al. 2003), particularly

498 vertebrates (Soule 1991), and urban wildlife generates numerous ecosystem services (Gómez-

499 Baggethun and Barton 2013). Therefore, there is a pressing need for understanding and

500 mitigating the sublethal consequences of urban life on wild vertebrates.

501

502

503

504

505

506

507

508

509

510

511

512

513 
514 Acknowledgements: S.J.C. is supported by the Natural Sciences and Engineering Research

515 Council of Canada (E.W.R. Steacie Fellowship, the Discovery Grant Program and the Strategic

516 Grant Program) and the Canada Research Chairs Program. Additional support is provided by

517 Carleton University and the US Fish and Wildlife Foundation through the United States Fish and

518 Wildlife Service Fish Enhancement, Mitigation and Research Fund for the St. Lawrence River.

519 R.dB. is supported by a Marie Curie Fellowship and the Max Plank Institute for Ornithology.

520

521

522

523

524

525

526

527

528

529

530

531

532

533

534

535

536 


\section{Literature Cited:}

538 Alberti, M. 1999. Urban patterns and environmental performance: what do we know?. J. Plan.

539 Edu. Res. 19: 151-163.

540

541 Alberti, M., Marzluff, J.M., Shulenberger, E., Bradley, G., Ryan, C., Zumbrunnen, C. 2003.

542 Integrating humans into ecology: opportunities and challenges for studying urban ecosystems.

543 BioSci. 53: 1169-1179.

544

545 Alberti, M., Marzluff, J.M. 2004. Ecological resilience in urban ecosystems: linking urban

546 patterns to human and ecological functions. Urban Ecosyst. 7: 241-265.

547

548 Alberti, M. 2005. The effects of urban patterns on ecosystem function. Int. Reg. Sci. Rev. 28:

$549 \quad 168-192$.

550

551 Alberti, M. 2008. Advances in urban ecology: integrating humans and ecological processes in 552 urban ecosystems. Springer, New York.

553

554 Alvey, A.A. 2006. Promoting and preserving biodiversity in the urban forest. Urban Forest.

555 Urban Green. 5: 195-201.

556

557 Andersson, E., Barthel, S., Borgström, S., Colding, J., Elmqvist, T., Folke, C., Gren, Å. 2014.

558 Reconnecting cities to the biosphere: Stewardship of green infrastructure and urban ecosystem 559 services. Ambio. 43: 445-453. 
561 Atkins, P.W. 1987. Molecules. Page 197. Freeman, New York.

562

563 Atwell, J.W., Ketterson, E.D. 2012. Boldness and stress physiology in a novel urban

564 environment suggest rapid evolutionary adaptation. Behav. Ecol. 23: 960-969.

565

566 Ball, J.E., Jenks, R., Aubourg, D. 1998. An assessment of the availability of pollutant

567 constituents on road surfaces. Sci. Total Environ. 209: 243-254.

568

569 Belanger, C.B., Vera-Chang, M.N., Moon, T.W., Midwood, J.D., Suski, C.D., Cooke, S.J. 2016.

570 Seasonal variation in baseline and maximum whole-body cortisol concentrations in small-bodied

571 stream fish independent of habitat quality. Comp. Biochem. Physiol. A: in press.

572

573 Bonier, F., Martin, P.R., Sheldon, K.S., Jensen, J.P., Foltz, S.L., Wingfield, J.C. 2007a. Sex-

574 specific consequences of life in the city. Behav. Ecol. 18: 121-129.

575

576 Bonier, F., Martin, P.R., Wingfield, J.C. 2007b. Urban birds have broader environmental

577 tolerance. Biol. Lett. 3: 670-673.

578

579 Bonier, F. 2012. Hormones in the city: Endocrine ecology of urban birds. Horm. Behav. 61: 763$580 \quad 772$.

581 
582 Booth, D.B., Karr, J.R., Schauman, S., Konrad, C.P., Morley, S.A., Larson, M.G., Burges, S.J.

583 2004. Reviving urban streams: land use, hydrology, biology, and human behavior. J. Am. Water

584 Resour. Assoc. 40: 1351-1364.

585

586 Bradley, C.A., Altizer, S. 2006. Urbanization and the ecology of wildlife diseases. Trends Ecol.

587 Evol. 22: 95-102.

588

589 Brazel, A., Selover, N., Vose, R., Heisler, G. (2000). The tale of two climates - Baltimore and

590 Phoenix urban LTER sites. Climate Res. 15: 123-135.

591

592 Brearley, G., McAlpine, C., Bell, S., Bradley, A. (2012). Influence of urban edges on stress in an 593 arboreal mammal: a case study of squirrel gliders in southeast Queensland, Australia. Landsc.

594 Ecol. 27: 1407-1419.

595

596 Breuste, J., Feldmann, H., Uhlmann, O. 2013. Urban Ecology. Springer Science \& Business

597 Media.

598

599 Brown, R.R., Farrelly, M.A., Loorbach, D.A. 2013. Actors working the institutions in

600 sustainability transitions: the case of Melbourne's stormwater management. Global Environ.

601 Change 23: 701-718.

602

603 Calow, P. 1991. Physiological costs of combating chemical toxicants: ecological implications.

604 Comp. Biochem. Physiol. 100: 3-6. 
606 Calow, P., Forbes, V.E. 1998. How do physiological responses to stress translate into ecological 607 and evolutionary processes?. Comp. Biochem. Physiol. A. 120: 11-16.

608

609 Candolin, U., Wong, B.B.M. 2012. Behavioural responses to a changing world: mechanisms and 610 consequences. Oxford University Press.

611

612 Castillas, E., Misitano, D., Johnson, L.L., Rhodes, L.D., Collier, T.K., Stein, J.E., McCain, B.B., 613 Varanasi, U. 1991. Inducibility of spawning and reproductive success of female English sole 614 (Parophrys vetulus) from urban and nonurban areas of Puget Sound, Washington. Mar Environ. 615 Res. 31: 99-122.

616

617 Chace, J.F., Walsh, J.J. 2006. Urban effects on native avifauna: a review. Landsc. Urban Plan. $618 \quad 74:$ 46-69.

619

620 Chiesura, A. 2004. The role of urban parks for the sustainable city. Landsc. Urban Plan. 68: 129621138.

622

623 Childe, V.G. 1950. The urban revolution. Town Plan. Rev. 21: 3-17.

624

625 Coffin, A.W. 2007. From roadkill to road ecology: a review of the ecological effects of roads. J. 626 Transp. Geog. 15: 396-406. 
628 Cohen, B. 2006. Urbanization in developing countries: Current trends, future projections, and 629 key challenges for sustainability. Tech. Soc. 28: 63-80.

630

631 Cooke, S.J., Blumstein, D.T., Buchholz, R., Caro, T., Fernández-Juricic, E., Franklin, C.E.,

632 Metcalfe, J., O’Connor, C.M., St. Clair, C.C., Sutherland, W.J., Wikelski, M. 2014. Physiology, 633 behaviour and conservation. Physiol. Biochem. Zool. 87: 1-14.

634

635 Coutant, C.C., Whitney, R.R. 2000. Fish behavior in relation to passage through hydropower 636 turbines: a review. Trans. Am. Fish. Soc. 129: 351-380.

637

638 Coyner, D.F., Spalding, M.G., Forrester, D.J. 2002. Epizootiology of Eustrongylides ingotus in 639 Florida: distribution, density, and natural infections in intermediate hosts. J. Wildl. Dis. 38: 483640499.

641 Cramp, S. 1972. The breeding of urban woodpigeons. Intern. J. Avian Sci. 114: 163-171.

643 Crino, O.L., Klaassen Van Oorschot, B., Johnson, E.E., Malisch, J.L., Breuner, C.W. 2011.

644 Proximity to a high-traffic road: Glucocorticoid and life history consequences for nestling white645 crowned sparrows. Gen. Comp. Endocrin. 173: 323-332.

646

647 Crooks, K.R. 2002. Relative sensitivities of mammalian carnivores to habitat fragmentation.

648 Conserv. Biol. 16: 488-502.

649

650 Cunniff, P.F. 1977. Environmental noise pollution. John Wiley \& Sons Inc. 
652 Dantzer, B., Fletcher, Q.E., Boonstra, R., Sheriff, M.J. 2014. Measures of physiological stress: a

653 transparent or opaque window into the status, management and conservation of species?.

654 Conserv. Physiol. 2: cou023.

655

656 Daszak, P., Cunningham, A.A., Hyatt, A.D. 2000. Emerging infectious diseases of wildlife:

657 threats to biodiversity and human health. Science. 287: 443-449.

658 Dhondt, A.A., DeCoste, J.C., Ley, D.H., Hochachka, W.M. 2014. Diverse wild bird host range of 659 Mycoplasma gallisepticum in Eastern North America. PLoS ONE 9, e103553.

660

661 Ditchkoff, S., Saalfeld, S., Gibson, C. 2006. Animal behavior in urban ecosystems: modifications 662 due to human-induced stress. Urban Ecosyst. 9: 5-12.

663

664 Dominoni, D., Quetting, M., Partecke, J. 2013. Artificial light at night advances avian

665 reproductive physiology. Proc. R. Soc. B 280: 20123017.

666

667 Flores, A., Pickett, S.T., Zipperer, W.C., Pouyat, R.V., Pirani, R. 1998. Adopting a modern

668 ecological view of the metropolitan landscape: the case of a greenspace system for the New York

669 City region. Landsc. Urban Plan. 39: 295-308.

670

671 Francis, C.D., Barber, J.R. 2013. A framework for understanding noise impacts on wildlife: an

672 urgent conservation priority. Front. Ecol. Environ. 11: 305-313.

673 
674 Francis, R.A., Lorimer, J. 2011. Urban reconciliation ecology: the potential of living roofs and

675 walls. J. Environ. Manage. 92: 1429-1437.

676

677 French, S.S., Fokidis, H.B., Moore, M.C. 2008. Variation in stress and innate immunity in the

678 tree lizard (Urosaurus ornatus) across an urban-rural gradient. J. Comp. Physiol. B 178: $997-$ 6791005.

680

681 Gehrt, S.D. 2007. Ecology of coyotes in urban landscapes. In Nolte, DL, Arjo, WM, Stalman, 682 DH, editors. Proceedings of the $12^{\text {th }}$ Wildlife Damage Management Conference.

683

684 Gehrt, S.D., Chelsvig, J.E. 2003. Bat activity in an urban landscape: patterns at the landscape and 685 microhabitat scale. Ecol. Appl. 13; 939-950.

686

687 Gehrt, S.D., Brown, J.L., Anchor, C. 2011. Is the urban coyote a misanthropic synanthrope? The 688 case from Chicago. Cities Environ. 4.

689

690 Goddard, M.A., Dougil, A.J., Benton, T.G. 2010. Scaling up from gardens: biodiversity

691 conservation in urban environments. Trends Ecol. Evol. 25: 90-98.

692

693 Gómez-Baggethun, E., Barton, D.N. 2013. Classifying and valuing ecosystem services for urban 694 planning. Ecol. Econ. 86: 235-245.

695 
696 Grieco, F., van Noordwijk, A.J., Visser, M.E. 2002. Evidence for the effect of learning on timing 697 of reproduction in blue tits. Science. 296: 136-138.

698

699 Grimm, N.B., Faeth, S.H., Golubiewski, N.E., Redman, C.L., Wu, J., Bai, X., Briggs, J.M. 2008.

700 Global change and the ecology of cities. Science. 319: 756-760.

701

702 Grinder, M.I., Krausman, P.R. 2001. Home range, habitat use, and nocturnal activity of coyotes 703 in an urban environment. J.Wildl. Manage. 65: 887-898.

704

705 Grubbs, S.E., Krausman, P.R. 2009. Use of urban landscape by coyotes. Southwest. Nat. 54: 170612.

707

708 Hall, S.J., Learned, J., Ruddell, B., Larson, K.L., Cavender-Bares, J., Bettez, N., Groffman, 709 P.M., Grove, J.M., Heffernan, J.B., Hobbie, S.E., Morse, J.L., Neill, C., Nelson, K.C., O’Neil-

710 Dunne, J.P.M., Ogden, L., Pataki, D.E., Pearse, W.D., Polsky, C., Chowdhury, R.R., Steele, 711 M.K., Trammell, T.L.E. 2016. Convergence of microclimate in residential landscapes across 712 diverse cities in the United States. Landsc. Ecol. 31: 101-117.

713

714 Helms, B.S., Feminella, J.W., Pan, S. 2005. Detection of biotic responses to urbanization using 715 fish assemblages from small streams of western Georgia, USA. Urban Ecosyst. 8: 39-57. 
717 Houlihan, D.F., Carter, C.G., McCarthy, I.D. 1995. Protein synthesis in fish. Pages 191-220 in:

718 Hochachka, P., Mommsen, T., editors. Biochemistry and Molecular Biology of Fishes. Elsevier, 719 Amsterdam.

720

721 Jansson, C., Ekman, J., von Bromssen, A. 1981. Winter mortality and food supply in tits Parus 722 spp. Oikos 37: 313-322.

723

724 Jones, G. 2008. Sensory ecology: noise annoys foraging bats. Curr. Biol. 18: R1098-1100.

725

726 Kleerekoper, L., van Esch, M., Baldiri Salcedo, T. 2012. How to make a city climate-proof,

727 addressing the urban island heat effect. Resour. Conserv. Recy. 64: 30-38.

728

729 Klem Jr, D. 1989. Bird: Window Collisions. The Wilson Bulletin, 606-620.

730

731 Kowarik, I. 2011. Novel urban ecosystems, biodiversity, and conservation. Environ. Pollut. 159:

732 1974-1983.

733

734 Kurta, A., Teramino, J.A. 1992. Bat community structure in an urban park. Ecograph. 15: 257735261.

736

737 Laiolo, P. 2010. The emerging significance of bioacoustics in animal species conservation. Biol.

738 Conserv. 143: 1635-1645.

739 
740 Larinier, M. 2001. Environmental issues, dams and fish migration. FAO Fish. Tech. Paper 419:

$741 \quad 45-89$.

742

743 Longcore, T., Rich, C. 2004. Ecological light pollution. Front. Ecol. Environ. 2: 191-198.

744

745 Lowry, H., Lill, A., Wong, B.B.M. 2013. Behavioural responses of wildlife to urban

746 environments. Biol. Rev. 88: 537-549.

747

748 Luniak, M. 1996. Synurbanization of animals as a factor increasing diversity of urban fauna.

749 Pages 566-575 in di Castri, F., Younes, T., editors. Biodiversity, science, and development:

750 toward a new partnership. CAB International.

751

752 Luniak, M. 2004. Synurbization-adaptation of animal wildlife to urban development. Pages 50-

75355 in Proceedings of the 4th International Symposium Urban Wildlife Conservation of Tucson.

754

755 Luniak, M., Pisarski, B. 1994. State of research into the fauna of Warsaw (up to 1990).

756 Memorabilia Zool. 49: 155-165.

757

758 Mage, D., Ozolins, G., Peterson, P., Webster, A., Orthofer, R., Vandeweerd, V., Gwynne, M.

759 1996. Urban air pollution in megacities of the world. Atmos. Environ. 30: 681-686.

760

761 Magle, S.B., Hunt, V.M., Vernon, M., Crooks, K.R. 2012. Urban wildlife research: past, present, 762 and future. Biol. Conserv. 155: 23-32. 
764 Mäkeläinen, S., de Knegt, H.J., Ovaskainen, O., Hanski, I.K. 2016. Home-range use patterns and 765 movements of the Siberian flying squirrel in urban forests: Effects of habitat composition and 766 connectivity. Mov. Ecol. 4: 1.

767

768 Margules, C.R., Pressey, R.L. 2000. Systematic conservation planning. Nature. 405: 243-253. 769

770 Marzluff, J.M., Bowman, R., Donnelly, R.E. 2001. A historical perspective on urban bird 771 research: trends, terms and approaches. Pages 1-18 in Marzluff JM, Bowman R, Donnelly RE, 772 editors. Avian conservation and ecology in an urbanizing world. Kluwer, New York.

773

774 Marzluff, J.M., Ewing, K. 2001. Restoration of fragmented landscapes for the conservation of 775 birds: a general framework and specific recommendations for urbanizing landscapes. Restor.

776 Ecol. 9: 280-292.

777

778 Marzluff, J.M., Neatherlin, E. (2006). Corvid response to human settlements and campgrounds:

779 causes, consequences, and challenges for conservation. Biol. Conserv. 130: 301-14.

780

781 McClennen, N., Wigglesworth, R.R., Anderson, S.H., Wachob, D.G. 2001. The effect of

782 suburban and agricultural development on the activity patterns of coyotes (Canis latrans). Am.

783 Midl. Nat. 146: 27-36.

784 
785 McClure, C.J.W., Ware, H.E., Carlisle, J., Kaltenecker, G., Barber, J.R. 2013. An experimental

786 investigation into the effects of traffic noise on distributions of birds: avoiding the phantom road.

787 Proc. R. Soc. B 280.

788

789 McDonnell, M.J. 2011. The history of urban ecology: an ecologist's perspective. Pages 5-13 in

790 Niemelä, J., Breuste, J., Elmqvist, T., Guntenspergen, G., James, P., McIntyre, N.E., editors.

791 Urban Ecology: Patterns, Processes and Applications. Oxford University Press, Oxford.

792

793 McEwen, B.S., Wingfield, J.C. 2003b. The concept of allostasis in biology and biomedicine.

794 Horm. Behav. 43: 28-30.

795

796 McKinney, M.L. 2002. Urbanization, biodiversity and conservation: the impacts of urbanization

797 on native species are poorly studies, but educating a highly urbanized human population about

798 these impacts can greatly improve species conservation in all ecosystems. BioSci. 52: 883-890.

799

800 McKinney, M.L. 2006. Urbanization as a major cause of biotic homogenization. Biol. Conserv.

801 127: 247-260.

802

803 Meillere, A., Brischoux, F., Angelier, F. 2015. Impact of chronic noise exposure on antipredator 804 behavior: an experiment in breeding house sparrows. Behav. Ecol.: in press.

805

806 Meyer, J.L., Paul, M.J., Taulbee, W.K. 2005. Stream ecosystem function in urbanizing

807 landscapes. Journal of the North American Benthol. Soc. 24: 602-612. 
809 Miller, M.A., Gardner, I.A., Kreuder, C., Paradies, D.M., Worcester, K.R., Jessup, D.A., Dodd, 810 E., Harris, M.D., Ames, J.A., Packham, A.E., Conrad, P.A. 2002. Coastal freshwater runoff is a 811 risk factor for Toxoplasma gondii infection of southern sea otters (Enhydra lutris nereis). Int. J. 812 Parasitol. 32: 997-1006.

813 Miranda, A.C., Schielzeth, H., Sonntag, T., Partecke, J. 2013. Urbanization and its effects on 814 personality traits: a result of microevolution or phenotypic plasticity? Glob. Change Biol. 19: $815 \quad 2634-2644$.

816

817 Morgan, I.J., McDonald, D.G., Wood, C.M. 2001. The cost of living for freshwater fish in a 818 warmer, more polluted world. Glob. Change Biol. 7: 345-355.

819

820 Morris, D.W. 2005. Paradoxical avoidance of enriched habitats: have we failed to appreciate 821 omnivores? Ecol. 86: 2568-2577.

822

823 Naguib, M. 2013. Living in a noisy world: indirect effects of noise on animal communication.

824 Behav. 150: 1069-1084.

825

826 Navara, K.J., Nelson, R.J. 2007. The dark side of light at night: physiological, epidemiological 827 and ecological consequences. J. Pineal Res. 43: 215-224.

828

829 Newsome, D., Rodger, K. 2008. To feed or not to feed: a contentious issue in wildlife tourism. 830 Pages 255-270 in Lunney D, Munn A, Meikle W, editors. Too close for comfort: contentious 
831 issues in human-wildlife encounters. Royal Zoological Society of New South Wales, Mosman, 832 Australia.

833

834 Niemelä, J. 1999. Is there a need for a theory of urban ecology?. Urban Ecosyst. 3: 57-65.

835

836 Oberweger, K., Goller, F. 2001. The metabolic cost of birdsong production. J. Exp. Biol. 204:

$837 \quad 3379-3388$.

838

839 O'Connell, A.F., Nichols, J.D., Karanth, K.U., editors. 2010. Camera traps in animal ecology:

840 methods and analyses. Springer Science \& Business Media.

841

842 Oke, T.R. 1973. City size and the urban heat island. Atmos. Environ. 7: 769-779.

843

844 Oke, T.R. 1995. The heat island of the urban boundary layer: characteristics, causes and effects.

845 Pages 81-107 in Wind Climate in Cities. Springer, Netherlands..

846

847 Onorato, D.P., Belden, C., Cunningham, M., Land, D., McBride, R., Roelke, M. 2010 Long-term

848 research on the Florida panther (Puma concolor coryi): historical findings and future obstacles to 849 population persistence. Pages 453-469 in Macdonald, D., Loveridge, A., editors. Biology and 850 Conservation of Wild Felids. Oxford University Press, Oxford, UK.

851

852 Oro, D., Genovart, M., Tavecchia, G., Fowler, M.S., Martinez-Abrain, A. 2013. Ecological and 853 evolutionary implications of food subsidies from humans. Ecol. Lett. 16: 1501-1514. 
855 Partecke, J., Van't Hof, T., Gwinner, E. 2005. Underlying physiological control of reproduction

856 in urban and forest-dwelling European blackbirds Turdus merula. J. Avian Biol. 36: 295-305.

857

858 Partecke, J., Schwabl, I., Gwinner, E. 2006. Stress and the city: urbanization and its effects on

859 the stress physiology in European blackbirds. Ecol. 87: 1945-1952.

860

861 Patricelli, G.L., Blickley, J.L. 2006. Avian communication in urban noise: causes and

862 consequences of vocal adjustment. Auk 123: 639-649.

863

864 Paul, M.J., Meyer, J.L. 2001. Streams in the urban landscape. Pages 207-231 in Urban Ecology. 865 Springer: USA.

866

867 Penuelas, J., Filella, I. 2001. Responses to a warming world. Science. 294: 793-794.

868

869 Pickett, S.T., Cadenasso, M.L., Grove, J.M., Groffman, P.M., Band, L.E., Boone, C.G., Law,

870 N.L. 2008. Beyond urban legends: an emerging framework of urban ecology, as illustrated by the

871 Baltimore Ecosystem Study. BioSci. 58: 139-150.

872

873 Plummer, K.E., Bearhop, S., Leech, D.I., Chamberlain, D.E., Blount, J.D. 2013. Winter food

874 provisioning reduces future breeding performance in a wild bird. Sci. Rep. 3: 1-6.

875 
876 Poessel, S.A., Burdett, C.L., Boydston, E.E., Lyren, L.M., Alonso, R.S., Fisher, R.N., Crooks,

877 K.R. 2014. Roads influence movement and home ranges of a fragmentation-sensitive carnivore,

878 the bobcat, in an urban landscape. Biol. Conserv. 180: 224-232.

879

880 Prange, S., Gerht, S.D., Wiggers, E.P. 2003. Demographic factors contributing to high raccoon

881 densities in urban landscapes. J. Wildl. Manage. 67: 324-333.

882

883 Raubenheimer, D., Simpson, S.J., Mayntz, D. 2009. Nutrition, ecology and nutritional ecology:

884 toward an integrated framework. Funct.Ecol. 23: 4-16.

885

886 Raubenheimer, D., Simpson, S.J., Tait, A.H. 2012. Match and mismatch: conservation

887 physiology, nutrition ecology and the timescales of biological adaptation. Phil. Trans. R. Soc. B.

888 367: 1628-1646.

889

890 Reid, S.D., Linton, T.K., Dockray, J.J., McDonald, D.G., Wood, C.M. 1998. Effects of chronic

891 sublethal ammonia and a simulated summer global warming scenario: protein synthesis in

892 juvenile rainbow trout (Oncorhynchus mykiss). Can. J. Fish. Aquat. Sci. 55: 1534-1544.

893 Rich, C., Longcore, T. 2013. Ecological consequences of artificial night lighting. Island Press,

894 Washington D.C.

895 Ricklefs, R.E., Wikelski, M. 2002. The physiology/life-history nexus. Trends. Ecol. Evol. 17:

$896 \quad 462-468$. 
898 Riley, S.P.D., Bromley, C., Poppenga, R.H., Uzal, F.A., Whited, L., Sauvajot, R.M. 2007.

899 Anticoagulant exposure and notoedric mange in bobcats and mountain lions in urban southern

900 California. J. Wildl. Manage. 71: 1874-1884.

901

902 Robb, G.N., McDonald, R.A., Chamberlain, D.E., Bearhop, S. 2008. Food for thought:

903 supplementary feeding as a driver of ecological change in avian populations. Front. Ecol.

904 Environ. 6: 476-484.

905

906 Robbins, P., Sharp, J. 2006. Turfgrass subjects: the political economy of urban monoculture.

907 Pages 106-123 in Heynen, N., Kaika, M., Swyngedouw, E., editors. The Nature of Cities: Urban 908 political ecology and the politics of urban metabolism. Routledge, London, UK.

909

910 Robbins, P., Polderman, A., Birkenholtz, T. 2001. Lawns and toxins: an ecology of the city.

911 Cities. 18: 369-380.

912

913 Rodewald, A.D., Kearns, L.J., Shustack, D.P. 2011. Anthropogenic resource subsidies decouple 914 predator-prey relationships. Ecol. Appl. 21: 936-943.

915

916 Roux, K.E., Marra, P.P. 2007. The presence and impact of environmental lead in passerine birds

917 along an urban to rural land use gradient. Arch. Environ. Contam. Toxicol. 53: 261-268.

918

919 Rubbo, M.J., Kiesecker, J.M. 2005. Amphibian breeding distribution in an urbanization

920 landscape. Conserv. Biol. 19: 504-511. 
922 Saggese, K., Korner-Nievergelt, F., Slagsvold, T., Amrhein, V. 2011. Wild bird feeding delays

923 start of dawn singing in the great tit. Anim, Behav. 81: 361-365.

924

925 Sakai, S., Sawell, S.E., Chandler, A.J., Eighmy, T.T., Kosson, D.S., Vehlow, J., Hjelmar, O.

926 1996. World trends in municipal solid waste management. Waste Manag. 16: 341-350.

927

928 Saldiva, P.H.N., King, M., Delmonte, V.L.C., Macchione, M., Parada, M.A.C., Daliberto, M.L.,

929 Sakae, R.S., Criado, P.M.P., Silveira, P.L.P., Zin, W.A., Böhm, G.M. 1992. Respiratory

930 Alterations due to urban air pollution: an experimental study in rats. Environ. Res. 57: 19-33.

931

932 Savard, J.P.L., Clergeau, P., Mennechez, G. 2000. Biodiversity concepts and urban ecosystems.

933 Landsc. Urban Plan. 48: 131-142.

934

935 Scheifler, R., Coeurdassier, M., Morilhat, C., Bernard, N., Faivre, B., Flicoteaux, P., Giraudoux, 936 P., Noel, M., Piotte, P., Rieffel, D., de Vaufleury, A., Badot, P.M. 2006. Lead concentrations in

937 feathers and blood of common blackbirds (Turdus merula) and in earthworms inhabiting

938 unpolluted and moderately polluted urban areas. Sci. Total Environ. 371: 197-205.

939

940 Schroeder, J., Nakagawa, S., Cleasby, I.R., Burke, T. 2012. Passerine birds breeding under

941 chronic noise experience reduced fitness. PLoS ONE 7: e39200.

942 
943 Serena, M., Pettigrove, V. 2005. Relationship of sediment toxicants and water quality to the 944 distribution of platypus in urban streams. J. North Am. Benthol. Soc. 24: 679-689.

945

946 Shannon, G., McKenna, M.F., Angeloni, L.M., Crooks, K.R., Fristrup, K.M., Brown, E., Warner, 947 K.A., Nelson, M.D., White, C., Briggs, J., McFarland, S., Wittemyer, G. 2015. A synthesis of 948 two decades of research documenting the effects of noise on wildlife. Biol. Rev. in press.

949

950 Sharma, S.K., Sanghi, R., editors. (2012). Advances in water treatment and pollution prevention. 951 Springer Science \& Business Media.

952

953 Sheriff, M.J., Dantzer, B., Delehanty, B., Palme, R., Boonstra, R. 2011. Measuring stress in 954 wildlife: techniques for quantifying glucocorticoids. Oecol. 166: 869-887.

955

956 Sih, A., Cote, J., Evans, M., Fogarty, S., Pruitt, J. 2012. Ecological implications of behavioural 957 syndromes. Ecol. Lett. 15: 278-289.

958

959 Simpson, S.J., Raubenheimer, D., Charleston, M.A., Clissold, F.J. 2013. Modelling nutritional 960 interactions: from individuals to communities. Trends Ecol. Evol. 25: 53-60.

961

962 Simpson, S.D., Meekan, M.G., Jeffs, A., Montgomery, J.C, McCauley, R.D. 2008. Settlement963 stage coral reef fish prefer the higher-frequency invertebrate-generated audible component of 964 reef noise. Anim. Behav. 75: 1861-1868.

965 
966 Slabbekoorn, H. 2013. Songs of the city: noise-dependent spectral plasticity in the acoustic

967 phenotype of urban birds. Anim. Behav. 85: 1089-1099.

968

969 Smith, B.R., Blumstein, D.T. 2008. Fitness consequences of personality: a meta-analysis. Behav.

970 Ecol. 19: 448-455.

971

972 Solokova, I.M., Lannig, G. 2008. Interactive effects of metal pollution and temperature on

973 metabolism in aquatic ectotherms: implications of global climate change. Clim. Res. 37: 181-

974201.

975

976 Sol, D., Lapeidra, O., Gonzalez-Lagos, C. 2013. Behavioural adjustments for a life in the city.

977 Anim. Behav. 85: 1101-1112.

978

979 Sorace, A., Gustin, M. 2009. Distribution of generalist and specialist predators along urban

980 gradients. Landsc. Urban Plan. 90: 111-118.

981

982 Soule, M.E. 1991. Land use planning and wildlife maintenance: guidelines for conserving

983 wildlife in an urban landscape. J. Am. Plan. Assoc. 57: 313-323.

984

985 Stein, S. 2014. Alien Squirrel. New York Magazine, New York.

986

987 Steyermark, A.C. 2002. A high standard metabolic rate constrains juvenile growth. J. Zool. 105:

$988 \quad 147-151$. 
990 Stracey, C.M. 2011. Resolving the urban nest predator paradox: the role of alternative foods for 991 nest predators. Biol. Conserv. 144: 1545-1552.

992

993 Strasser, E.H., Heath, J.A. 2011. Effects of developmental conditions on nestling American 994 kestrel (falco sparverius) corticosterone concentrations. Gen. Comp. Endocrin. 173: 164-170. 995

996 Sun, J.W.C., Narins, P.M. 2005. Anthropogenic sounds differentially affect amphibian call rate. 997 Biol. Conserv. 121: 419-427.

998

999 Tigas, L.A., Van Vuren, D.H., Sauvajot, R.M. 2002. Behavioral responses of bobcats and 1000 coyotes to habitat fragmentation and corridors in an urban environment. Biol. Conserv. 108: 2991001306.

1002

1003 Tompkins, D., Sainsbury, A.W., Nettleton, P., Buxton, D., Gurnell, J. 2002 Parapoxvirus causes 1004 a deleterious disease of red squirrels associated with UK population declines. Proc. R. Soc. B. 1005 269: 529-533.

1006 Tremblay, M.A., St Clair, C.C. 2009. Factors affecting the permeability of transportation and 1007 riparian corridors to the movements of songbirds in an urban landscape. J. Appl. Ecol. 46: 1314$1008 \quad 1322$

1009

1010 United Nations Population Fund. (2007). State of the world population 2007: unleashing the 1011 potential of urban growth. United Nations Population Fund, New York. 
1013 Vitousek, P.M., Mooney, H.A., Lubchenco, J., Melillo, J.M. 1997. Human domination of earth’s 1014 ecosystems. Science. 277: 494-499.

1015

1016 Walcott, C.F. 1974. Changes in bird life in Cambridge, Massachusetts from 1860 to 1964. Auk. 1017 91: 151-160.

1018

1019 Walsh, C.J., Roy, A.H., Feminella, J.W., Cottingham, P.D., Groffman, P.M., Morgan II, R.P. 1020 2005. The urban stream syndrome: current knowledge and the search for a cure. J. North. Am. 1021 Benthol. Soc. 24: 706-723.

1022

1023 Ware, H.E., McClure, C.J.W., Carlisle, J.D., Barber, J.R. 2015. A phantom road experiment 1024 reveals traffic noise is an invisible source of habitat degradation. Proc. Nat. Acad. Sci. 112: $1025 \quad 12105-12109$.

1026

1027 Warren Jr, M.L., Pardew, M.G. 1998. Road crossings as barriers to small-stream fish movement. 1028 Trans. Am. Fish. Soc. 127: 637-644.

1029

1030 Wauters, L.A., Grunell, J. 1999. The mechanism of replacement of red by grey squirrels: a test of 1031 the interference competition hypothesis. Ethology. 105: 1053-1071.

1032 Werry, J.M., Lee, S.Y., Lemckert, C.J., Otway, N.M. 2012. Natural or artificial? Habitat-use by 1033 the bull shark, Carcharhinus leucas. PloS ONE 7: e49796. 
1035 Widder, P.D., Bidwell, J.R. 2009. Tadpole size, cholinesterase activity, and swim speed in four 1036 frog species after exposure to sub-lethal concentrations of chlorpyrifos. Aquat. Toxicol. 88: 9-18.

1037

1038 Wilson, A.D.M., Wikelski, M., Wilson, R.P., Cooke, S.J. 2015. Utility of biological sensor tags 1039 in animal conservation. Conserv. Biol. 29:1065-1075.

1040

1041 Zannin, P.H.T., Ferreira, A.M.C., Szeremetta, B. 2006. Evaluation of noise pollution in urban

1042 parks. Environ. Monit. Asses. 118: 423-433.

1043

1044

1045

1046

1047

1048

1049

1050

1051

1052

1053

1054

1055

1056

1057 


\section{Figure Captions}

1059 Figure 2. Overview of the potential challenges that urbanization poses on wild vertebrates. City

1060 lights can greatly affect migratory species and circadian rhythms. Large factories can participate

1061 in generating heat islands and pollution. Vehicles and boats pollute the surrounding environment

1062 through exhaust. Stream water runoff can severely impact the water quality of streams, having

1063 effects on fish populations. Noise can impair intraspecific communication.

1064

1065 


\section{Figure 1 - Synurbanization}

Synurbanization refers to the adaptation of wildlife to urban environments (reviewed by Luniak 2004). The study of synurbanization has grown recently, as we try to tease apart the degree to which phenotypic plasticity and microevolutionary processes leading to divergent selection contribute to changes in animals under human-altered conditions. The creation of a new urban ecosystem has benefitted some animals, namely small mammals and birds. These species have adjusted to urban pressures through higher population densities, reduced migratory behavior, prolonged breeding seasons, greater longevity, prolonged circadian rhythms, and changes in feeding behavior (as listed in Luniak 1996). For example, many birds benefit from supplementary feeding in urban areas, leading to earlier lay dates, larger clutches and chicks, and higher hatching and fledging success (reviewed in Robb et al. 2008). Top-down processes may also affect these species, as predation pressure may be reduced when predators shift their diet to anthropogenic sources (Rodewald et al. 2011; Stracey 2011). More omnivorous species can mitigate the costs of searching for and killing live prey by modifying their behavior to depend on anthropogenic food, a trend that is becoming increasingly apparent for coyotes, raccoons, and black bears (Prange et al. 2003; Gehrt 2007). Urban populations also tend to be more aggressive, take more risks, are less neophobic, are more exploratory/bold and have reduced escape behaviors compared to rural populations (Miranda et al 2013; Sih et al 2012). These personality traits can be linked to fitness: bolder and more aggressive individuals have greater reproductive success, and exploratory individuals have higher survival (Smith and Blumstein 2008), suggesting these personality traits are beneficial when inhabiting a novel and risky urban environment. The home ranges of both bats (Gehrt and Chelving 2003) and coyotes (Canis latrans) (McClennen et al. 2001, Grubbs and Krausman 2009) did not differ between fragmented and unfragmented habitats, and both species used human-generated corridors during travel, suggesting that species which can persist in urban environments (i.e., synanthropes, Gerht et al. 2011) are able to adjust their behavior to habitat fragmentation and human activities. Studies integrating bottomup and top-down ecological interactions with behaviour and physiology and linking these traits with fitness are sorely needed, as the sublethal consequences of urban modifications are both acute and chronic. 1a) A fox (Vulpes vulpes) is walking in a residential area at night, and 1b) a grey heron (Ardea cinerea) has acquired food from a local street vendor in Amsterdam. Images by Sam Hobson
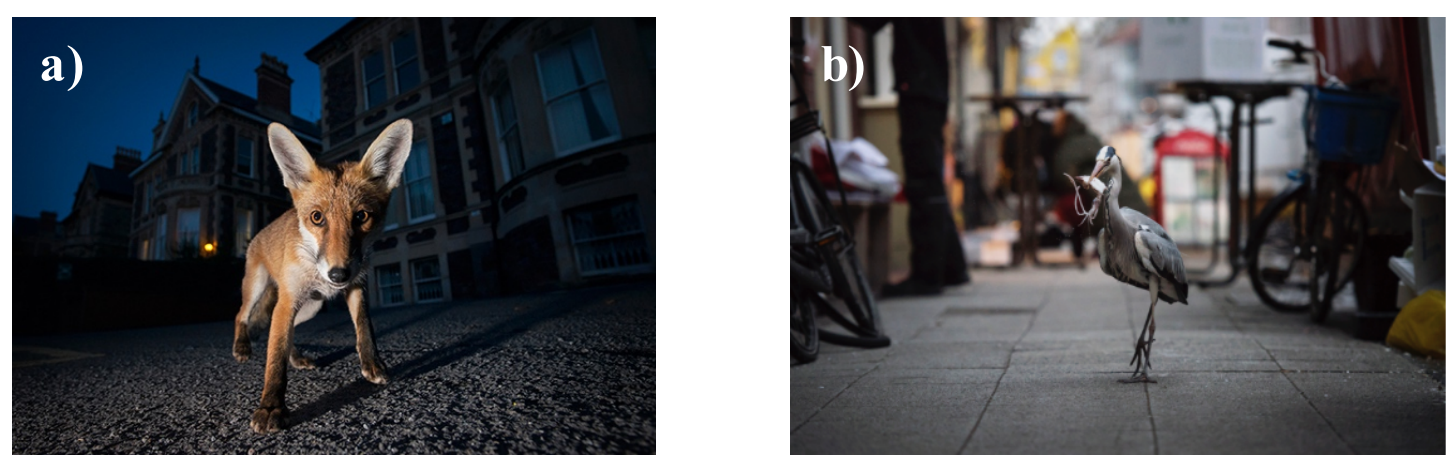


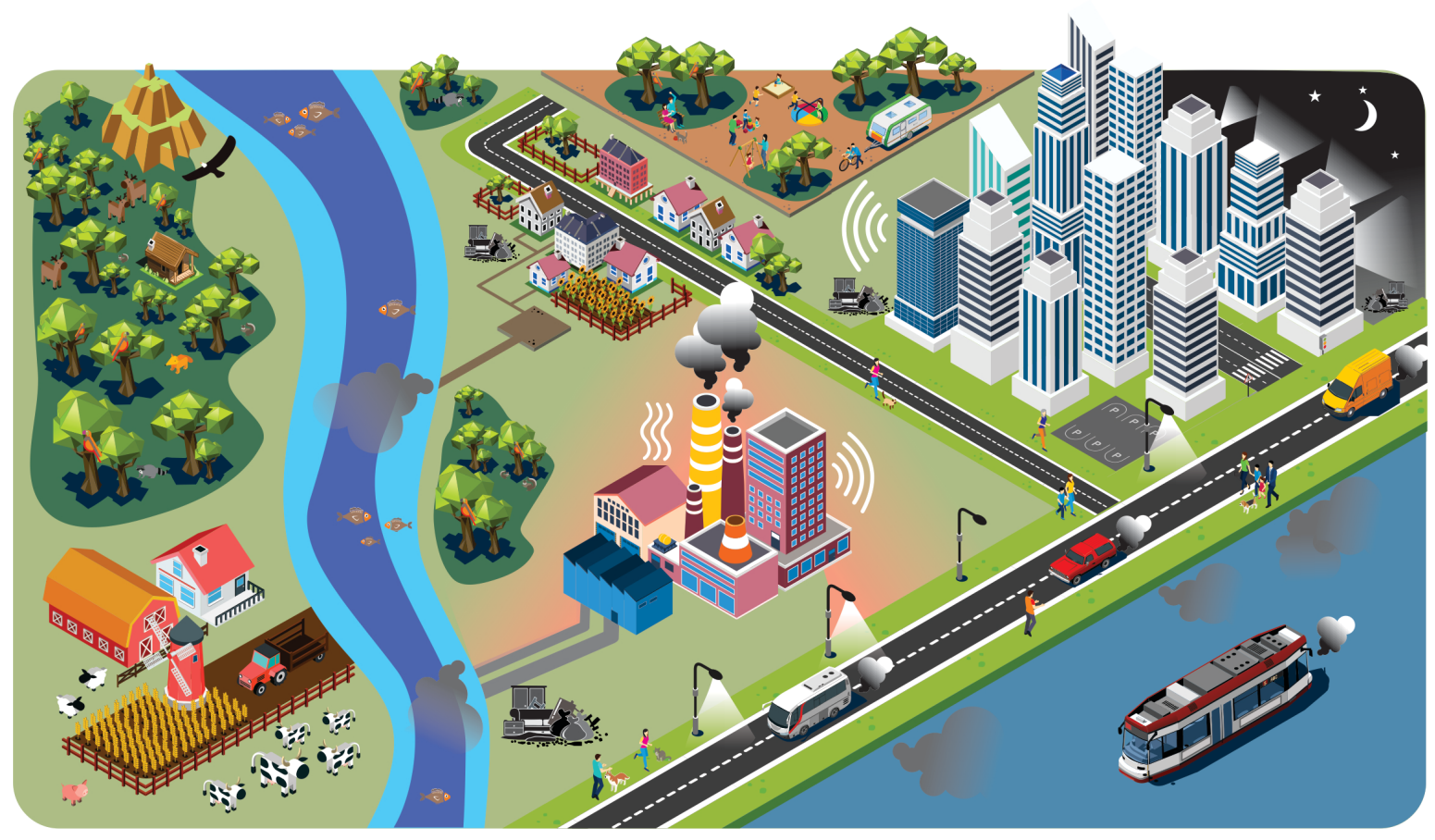




\section{Figure 3 - Making cities more liveable: success stories}

3a) Every year, billions of birds migrate north in the spring and south in the fall. Many species will do so at night, when the presence of lights from buildings and other structures can cause severe disturbances to bird's navigation as they fly over. Lights Out is a national effort in the USA that aims to reduce this issue by simply convincing building owners and managers to turn off excess lighting at night during the months that birds are migrating. Image by NASA

3b) Discouraging open lawns on public and private property was successful in restoring some wildlife habitat in King County, Washington. The many layers of undisturbed habitat provide a complex and favorable environment for small mammals and birds. Image by Wave Hill

3c) In Melbourne, Australia, stormwater infrastructure was altered over the course of almost two decades to improve the city's waterways. They used community members, environmental scientists and policy-makers to establish a plan to make a smoother transition to a more sustainable infrastructure (Brown et al. 2013). Image by Storm Water Systems
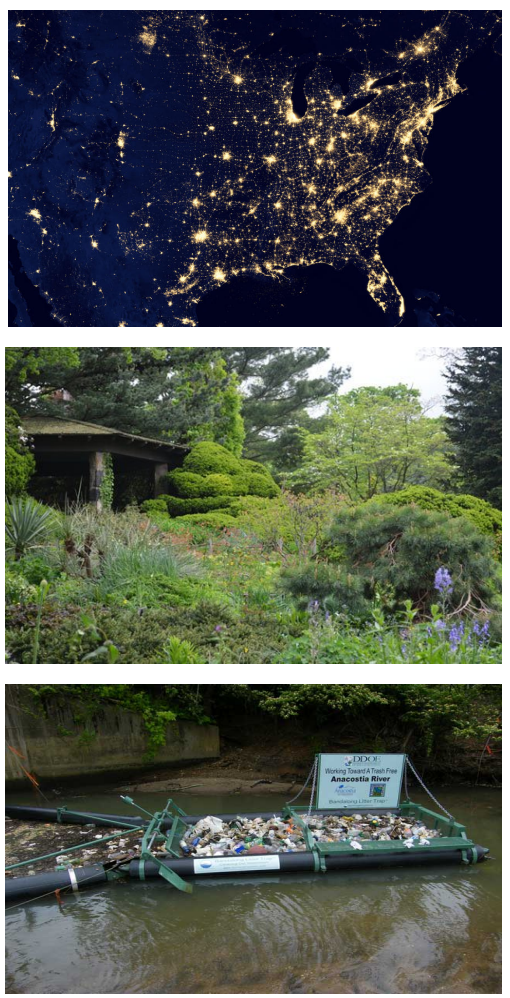